\title{
The pattern of collective memory denial experienced by the student victims' mothers of 1998-1999 Trisakti-Semanggi Tragedy
}

\author{
Pola pengingkaran ingatan kolektif yang dialami oleh keluarga korban \\ mahasiswa yang meninggal pada Tragedi Trisakti-Semanggi 1998-1999
}

\author{
Rizqy Amelia Zein \& Ilham Nur Alfian \\ Department of Personality and Social Psychology, Faculty of Psychology, Universitas Airlangga \\ Kampus B Universitas Airlangga, Jalan Airlangga 4-6 Surabaya, East Java 60286 \\ E-mail: amelia.zein@psikologi.unair.ac.id; ilham.nuralfian@psikologi.unair.ac.id
}

\begin{abstract}
This research aimed to uncover collective memory denial of the victims' families of Students who died in Trisakti and Semanggi Tragedy 1998-1999. We described how this pattern of collective memory denial works. This research used the qualitative approach to the instrumental case study. The participants were three mothers of students who died in Trisakti and Semanggi tragedy. We carried out interviews and field note as data collecting technique. This data was analysed using thematic analysis technique. The result showed that there is a denial of collective memory which is experienced by victims' families of students who died at Trisakti and Semanggi tragedy. The pattern is formed systematically, orderly, and deliberately. This denial showed that the government deliberately prevented the people to remember this tragedy. Collective memory denial causes so many negative effects, such as conspiracy of silence on the people and second victimization for victims' families. Moreover, these effects included the form of prejudice, mistrust, aversion, and vengeance between the people. When social sharing continuously assembles, it will finish the emotional problem of a negative event. On the other hand, social sharing will develop subjective well-being of the people in that community, not only in short-term, but also in long-term. Collective memory which is healthy distributed, motivates the community to discuss, express, and cope the painful trauma in the past.
\end{abstract}

Keywords: denial; collective memory; victims’ families; Trisakti and Semanggi Tragedy

\begin{abstract}
Abstrak
Penelitian ini bertujuan untuk mengungkap pengingkaran ingatan kolektif yang dialami oleh keluarga mahasiswa korban Tragedi Trisakti dan Semanggi 1998-1999. Penelitian ini mendeskripsikan bagaimana pola pengingkaran tersebut bekerja. Penelitian ini merupakan penelitian kualitatif dengan menggunakan pendekatan studi kasus. Informan penelitian ini adalah tiga ibu kandung dari mahasiswa yang meninggal ditembak pada peristiwa Trisakti, Semanggi I dan Semanggi II. Data dianalisis dengan menggunakan analisis tematik. Hasil penelitian menunjukkan bahwa pengingkaran ingatan kolektif dilakukan secara sistematis, teratur dan disengaja. Pengingkaran ini menunjukkan bahwa pemerintah sengaja menghalang-halangi masyarakat untuk mengingat kembali peristiwa tersebut. Pengingkaran ingatan kolektif menimbulkan banyak akibat negatif, seperti conspiracy of silence dan viktimisasi kedua yang dialami oleh korban. Efek lain yang ditimbulkan adalah timbulnya prasangka, ketidakpercayaan, permusuhan dan dendam di antara masyarakat. Di sisi lain, social sharing akan berpotensi meningkatkan kesejahteraan subjektif masyarakat, tidak hanya jangka pendek, melainkan juga jangka panjang. Ingatan kolektifyang terdistribusi secara sehat akan membantu suatu komunitas untuk mendiskusikan, mengekspresikan dan memulihkan diri dengan baik dari trauma yang menyakitkan di masa lalu.
\end{abstract}

Kata kunci: pengingkaran; ingatan kolektif; keluarga korban; Tragedi Semanggi dan Trisakti

\section{Introduction}

The violation of humanity becomes an enigmatic problem that is difficult to resolve and to reconcile in Indonesia. Militaristic approach, which goes identically with violence and massacre, in fact, are applied routinely when it compares to a more humanistic way to cope with political instability. Political assassinations that already happened in Indonesia, such as 1965 tragedy, Malari, Petrus, Tanjung Priok, tragedy Trisakti-Semanggi (TSS), and the policy of Regional Military Operations (DOM) in various place, in fact, incarnate as political interest tools rather than enhancing security and stability. Terror activity served as a regime's favourite tool to achieve legitimacy and to secure 
their power. However, using achieving political stability to justify state-orchestrated terror cannot be understood in a sense way. It is difficult to understand how could one possibly commit murders for the sake of creating a sense of security and stability.

Every conflict always results two competing sides; the victims and the perpetrators, where the conflict between them are usually left unsolved, wrote Cohen (2011) in his book "States of Denial". The state's way to solve this problem is often harming the victims' feeling, reduce the problem substance, along with the denial towards the victims' memory that tipped to the massive abuse of justice.

Trisakti-Semanggi (TSS) incident that happened twelve years ago leaving an unanswered question for most Indonesians. The tragedy made more than 33 died victims and hundreds other wounded, but we had no satisfying reconciliation thus it slowly begins to decay in the history of Indonesia. The government is silent, reluctant to answer the demands of the people to show some responsibility, to show serious efforts to uncover, and to explain what actually happened before, during and after the tragedy. The official history, nevertheless, recognized the victims as rebels and their death was merely a punishment from the law enforcement. Instead, the government even acts repressively by trying to deeply bury the collective memory of the victims' Trisakti tragedy that happened in May 1998, Semanggi I in November 1998, also Semanggi II in September 1999 (Haryatmoko 2003).

In a definitive way, the collective memory is a concept to draw how a society able to remember, forget, or place their past memory (Kuzmanic 2008). Therefore, it is important for a nation to build their collective memory, because of it able to portray how the history of the society past was constructed, hence we are able to understand the social situation and social identity. The collective identity also can be understood as a historical interpretation of a nation which served as representation effort to reinforce the national identity and legitimate the social institution inside the society. For example, the formation of the Indonesian nation, geographically, is a representation of historical interpretation of Majapahit Empire in the past.

The research that was done by Pennebaker (in Berinstain et al. 2000) shows that the crucial events that brought huge change were easier to be part of collective memory more than daily life event. This collective memory is able to push the form of cohesiveness as well as forming the pulse rhythm inside the group. The collective memory also gives a reason for the group to do groups' action, along with pushing the individual to evaluate the group action which then formed a social identity.

The collective memory has important implication towards social condition, culture, and politics because it feels as the individual perception to another individual inside their social group and the important event that experience by their social group. The consequence that causes by this situation is action and reaction by that individual towards their social environment. The collective memory which shared together have the important influence of the construction creation and communication of an event, interpersonal relations, social group history, the government and public policy, that portray the uniqueness and character of that group (Weldon \& Bellinger 1997).

The research about the memory as social phenomena, Wattimena (2008) based on the social distribution process inside the society whenever they remember a crucial event that happened to them. Indeed, the memory is an individual symptom, because the individual cognition that able to remember. Nonetheless, we cannot forget if the distribution process from individual memory has functions and impact that have a social character. The collective memory about political catastrophe is a memory that distributes in a group way to each individual inside that group. The events, in fact, not institutionalized inside the certain historical ceremony, except for several cases, precisely suppressed and denied. Even though being suppressed and denied, the collective memory not directly disappears, but it still survives and then become a legend, tradition, and thicken as a culture. Moreover, the social conflict that suppressed in a repressive way would potentially undermine the society trust to the government (Wartiharjono 2017).

Several social psychology experts emphasize that the collective memory is a psychological process that moves beyond the individual psychology process in the society context. This psychology process 
based on the individual activity, but the process has their own autonomy. Garzon \& Rodriguez (1998) stated that psychology process was able interpreted as a collective process of memory. This collective process becomes the interesting reflection them in social psychology. This paradigm stated that someone cognitive process not only being interpreted naively as purely personal action but rather as a contribution action, that able to modify and possess significant impact towards the social environment.

The memory of a nation about a negative event that happened to them will tend to be buried and to be avoided to talk about. The buried collective memory, Wattimena (2008) will create social trauma. This then influences the cultural mentality of a nation as well as creates the identity crisis. The identity crisis that experienced by the nation, not only caused by the inability to constructs but more to the unwillingness to reflect and institutionalized in just way as the history that occurred one after another.

Besides its painful memory, the reason when people are reluctant to talk about the trauma is they trying to blur the cruelty facts. The blurring of history has becoming an apology that usually used to negate the crime that happened in the past (Hardiman 2005). If the facts were revealed then to be prosecuted and institutionally institutionalized, it will create an extraordinary moral anxiety that will be experienced by the community. This is the sacrifice that appropriates for the restoration and preservation of collective memory. Through, the collective memory we are able to study to destroy the roots of racism, false fundamentalism and nationalism, fascism and others, which usually were seen in the mass conflict in some part of the world such as Tibet, Indonesia, Rwanda, Uganda, Balkan region and South America. Through collective memory institution, it is able to form a constructive and reflective perception of Indonesia nation as national identity (Wattimena 2008).

After twelve years, the memory of the society towards the Trisakti Tragedy, Semanggi I, and Semanggi II blurring without emotion because it defeated by other painful emotions. This condition at glance seems natural, however, when they realize it or not, we will drag inside forgetting mechanism as well as structures denial that done by the government. Minimum there are ten of state-organized denial towards human rights violation (Cohen 2001).

The last report of Commission of Infringement Investigation Human Rights (KPPHAM) upon Trisakti tragedy, Semanggi I and II (TSS) that finished since March 2002 was one of concrete prove as one model of state-organized denial. Since in the beginning, it clearly had seen that there was a willingness to extend the time to uncover this tragedy through the legal path. Various reason was put forward, start from the absence the oath of office for KPP HAM TSS staff, reports that are considered have many drawbacks, until with the latest reasons that used by Attorney General, that the TSS case has been freed from demand the establishment Human Rights ad hoc court, because the political recommendation that issued by DPR 1999-2004 period, reject the establishment of this institution. Whereas the establishment of Human Rights ad hoc court also served as the recommendation that given by KPP HAM TSS (Bonasahat 2007).

This public statement that release by several military officials that strongly alleged involve in this case, even more, add suspiciousness the people of Indonesia, organized denial and collective memory denial is true. Wiranto, former Commander of the Armed Forces at that time, ask all the people to not being trapped in the past (Bonasahat 2007). Besides, the former Deputy Chief of Staff of the Army Kiki Syahnakri released a similar statement in the middle of the ceremony of the handover of position, ask the people not to mention the past (Bonasahat 2007). From the two facts that have been mentioned, difficult for the government to deny the allegations if there is an effort to deny systematically of the collective memory for the sake to strengthen the government bargaining position that safer without any disruption because the effect is the legitimacy towards the running government. The silencing efforts were used to muffle the victims' feeling and avoid the occurrence of collective actions such as larger social movement that will bring disadvantage for the government (Lykes 1994).

The blurring of law supremacy towards crimes against humanity precisely hurts the victims' feeling 
and their family for the second time. Since that they already face traumatic events that unforgettable, as well as have to face the undefeated enemy that is coercion and pressure from certain people to forget their collective memory. This situation is called second victimization. Besides that, they were not recognized as the victim, silenced, hated, and declared as a lie that never happened and they were accused as the states' enemy. It creates the impunity culture, the fear of questioning again, and the most severe, and neglect, does not care towards the crime that happened. Particularly when the victim was reluctant to be acknowledged, clearance their trauma and given their rights. It will make perpetrator more arrogant since that they could escape from legal punishment. This culture able to guide Indonesian facing identity blurring and create the impunity culture that gives legitimacy if crimes against humanity which the purpose was to build security stability are rightful and do not need to be sanctioned. The thing that may be forgotten for the ruler is that collective memory is very different from individual memory. If individual memory could disappear along with the death of the owner, while the collective memory would never die. They will continue to demand their forgotten rights, as well as demand the justice. They will continue questioning until the victims' being acknowledge and turns it into a part of history, and no longer as the history of the losers (Haryatmoko 2003, Wattimena 2008).

Both individual trauma and social trauma must be surpassed properly by the sufferer. In Trisakti tragedy and Semanggi, the family victims until now still demand justice by using various efforts, such as by establishing JSKK (Jaringan Solidaritas Korban Untuk Keadilan). By the existence of $J S K K$, it expected to be able completing the victims' family efforts to revive the collective memory of this nation. Before the apologies for the word being said from the victims' family, the historical recognition was supposed to be done and the complaint efforts and protest towards injustice that done by the family must be run in accordance with the legal procedure that previously agreed on.

In other words, before the victims' remission achieves the forgiveness, there supposed a remission effort that institutionalized-legal, which is through enforcement legal sanctions (Wattimena 2008). Nevertheless, it necessary to be noticed, the forgiveness must be differentiated with legal sanction. Although, the victims' family already sincerely forgive the perpetrator, not then become a reason to drag the perpetrator to the court. The law does not only function as solve the social conflict but more importantly, it turns as tools towards more civilized life. The legal process is an infrastructure to revive the collective memory and to prevent the recurrence the same crime against humanity. The forgiveness, islah or amnesty suit with its means after the legal process has taken place. The legal process was not intended as a revenge tool but served to institutionalize the collective memory of the past crimes that tend not to be acknowledged (Haryatmoko 2003).

Finally, the society and history record the Trisakti and Semanggi tragedy is the event that must be avoided, not as a means of justifying the use of violent methods as a way to build security stability. It can be interpreted as the approval towards crimes against humanity, so it will possible if the similar crimes, which also even cruel, happened again for the several times in the future.

The impunity culture to the human rights violator and identity crisis, as well as nationalism crisis seems, can be caused the inability of this nation to face, acknowledge, and forgive their own past, and always form their identity through buried collective memory which is called a conspiracy of silence. Wattimena (2008) emphasized in this article if the conspiracy of silence play important role in shaping the society culture right now. Indonesian people are the people who have silence tendency while talking about their past, as results the national identity shaped in silence. The oppressor often makes the modernization as a rationalization by making evil just only as a technical problem that can be solved through legal means, organization, forensics and genetics. The modernity, silence towards the evil as the metaphysic problem and degrade it within criminology or pathology. Ideally, the modernity product is a way that supposed to deliver the constructive contemplation. If we tend to give attention to the modernity products more than its substance, then these products tend to be manipulated that makes us unable to achieve the justice substance that supposedly to be owned. Because like it or not, we are facing the reality that the repressive person was able to do everything to avoid legal sanction (Hardiman 2005). 
Avoiding talking about trauma will only create a deep gap. The reconciliation process wishes the reduction gap between the victims and the perpetrators. The victims must be dealt properly with the victim, and the perpetrator also dealt properly as the perpetrator, however, in fact, what truly happened is the second victimization paradox. It happened whenever law supremacy is poor, victims and family then forcefully silenced, along with silenced other people who non-victims to forget the events through silence conspiracy. The perpetrators and its cronies ask people to understand those events, which resulting that no one assumes the event was ever happened, further, no one who is brave to recall that dark past. The victim could afford to recall their past, let alone to prosecute the perpetrators. Therefore, this problem creates the deep gap between the victims and the perpetrators (Haryatmoko 2008).

The gap problem between the victim-perpetrator was interesting to be observed, that this kind of problem gap is common within the risky society, which the society that often surprised by the surprising changes that come and go, Which means that, the modern society has a class structure within it (Beck 1992).

In the end, we are required to be honest about the past that ever happened. The cruelty that ever happened in the history of Indonesia nation and it is time for us to take it to the level of consciousness. This action is an urgent demand for us to do today. When there are honesty and justice towards the past, the collective memory distribution becomes smoother so that people are able to construct their perception of the nation in a pleasant way.

Therefore, this research aimed to systematically narrate the pattern of collective memory denial that experienced by the victims' family of Trisakti and Semanggi tragedy that already happened twelve years ago. As a reminder for the government and Indonesian people to give more attention towards the victims' family that face oppression because of the difficulties of political situations. Besides that, another purpose is to push the government in preparing rehabilitative and anticipatory steps when dealing with victims' family in order there would not happen second victimization to them.

\section{Research Method}

This research is qualitative inductive research, which means that the author not limit the research framework in rejection and acceptance efforts towards certain allegations or hypotheses, but to understand and portraying contexts and situations that happen as it is (Poerwandari 2007, Patton 2001). The consequence, the author receives the presence of unexpected facts that might appear during data collection.

The approach that used in this research is a case study. The case study is understood as special unique phenomena, which are present in a limited context, although the boundaries between phenomena and contexts are not entirely clear. The case study can be individual, role, group, organization, community or even a nation (Poerwandari 2007). The case study that author used in this research is case study instrumental which means as an exploration as one certain case to understand the issue better. Which mean that the informant who involves in this research played a role as means or tools for the author to understand the case.

The assumptions that author used in this research is research informant have a uniqueness of the characteristics' life experience; in this case is the experience when they face the case of violence and violence trauma that experienced by their son. The case study approach is chosen because of it able to dig and understand the informant perspective deeper within the natural context.

The informant in this research is the biological mother from students' victim who died in Trisakti and Semanggi tragedy, which also involved as member JSKK community who actively involve throughout the advocacy activities and/or following Kamisan action. The biological mother that selected in this research was usually involved as JSKK member as well as actively followed the advocacy activities and case commemoration with JSKK and KontraS. Besides that, the member of 
$J S K K$ was largely the mother of the victim who died in the tragedy. The informant candidate who then chosen as the informant, besides meet the above criteria, they must state the willingness to be an informant. The researcher only obtains one informant candidate, who finally turns to be the first informant and then ask her to chose another potential informant that suitable for the criteria.

From four people who meet with the informants' criteria, only three people who willingly participate in this research and turns them into the key informants. Those informants are (a) Mrs SM, the mother of Bernardus Realino Norma Irmawan the victim from Semanggi I tragedy, (b) Mrs HON, the mother of Yap Yun Hap the victim from Semanggi II tragedy, (c) Mrs TT, the mother of Elang Mulia Lesmana the victim from Trisakti tragedy. The interview conducted with time span December 2010-January 2011.

The data extracting technique that used in this research is a semi-structured interview. Where the meaning of interview is conversation and question and answer that done by the author to explore the case and answering the research question.

In choosing interview technique as data extracting process was done with considering the needs of data specific and deep about the subjective meaning which understood by the informant as well significant other, thus it able to be analyzed in the sharp and deep way. Moreover, the conformity between the method that used by the author along with the research purpose is the representation from one of aspect dependability, that is coherence (Poerwandari 2007). Dependability is a concept to replace the reliability of qualitative research. Besides applying coherence aspect, the researcher also applying openness, by using application of different methods, such as interview and field record to obtain the data.

Patton (2001) explained that the semi-structured technique on the interview is used general guideline where the issues must be explored without determining the questions order. The general issues were structured in order to keep the conversation in parallel with the research topic as well as direct it to the certain aspect from the life or experience from the informant which related to the case study.

The interview guideline was arranged systematically by following the theoretical direction about the victims' family perception towards the memory denial that done by the state from Cohen (2001), Seroussi \& Teeger (2010), Zerubavel (2006), and Welch (2003). The interview guideline also used the time sequence order with the purpose to make informants easier in explaining their experience as well as reflect it when facing the collective memory denial towards violence case that done by the state. Through the sequence of experience and reflection that disclosed by the informant, then it can be know how the pattern of collective memory denial.

Besides using interview technique, the data completeness will be supported by the observation record during the interview. The observation in here is not the data extracting technique that separated with the interview, but the observation becomes uniting with the interview method. The observation record contains the description of the observed things which is considered important as well as the interesting interaction between interviewer and the informant during the interview.

The data extracting technique which is then used by the researcher is making the fields notes. This note is used to give concrete and details description about the researcher observation towards Kamisan action event that routinely done by the informant. The researcher observed the 168th Kamisan action in Thursday, $25^{\text {th }}$ November 2010. This field notes become the important resources for the researcher to arrange the report and data analysis (Poerwandari 2007). It contains: (a) contexts description; (b) the description about the people who are being observed; (c) the description about who doing the observation; (d) the description about the perpetrator that showed by the observed people; (e) the temporary interpretation researcher towards the observed events; (f) explored the feelings and cognition of the researcher to the observed events (Baninster et al. 1994 in Poerwandari 2007).

As for the collecting tools are the voice recorder, paper, and pencil. All the data that were recorded will be retyped and will be in the form of written data. Then the data will be analyzed 
by using a theoretical framework that has been explained previously. Besides that, the researcher completes the data research by using the documentation data such as the photograph from $167^{\text {th }}$ Kamisan action, then followed by arranging the field notes. The data that has been collected accordingly organized by coding technique, the analyzed by using thematic analysis technique.

\section{Results and Discussion}

Based on the research result which formulated by the researcher, it firmly shows that there were efforts the collective memory denial that done by the state to the victims' family TSS. In the research, Berinstain (2000) and Wattimena (2008) explained that the state indeed tends to do a denial towards the negative phenomena which happened in the past. The negative memory that experienced by a group tends to be buried, blurred, and forgotten. This call by Halbwachs (1992) as a traumatic political event and potentially form social trauma. The implication of the social trauma it could shape the horizontal conflict (because of the pro-contra polarization) within the society. As well as potentially cause the identity crisis of a nation. Moreover, the repression that came from the collective memory capable of forming the nations' cultural mentality who was accustomed to living together with fear.

This denial, Cohen (2001) in his book aim to prevent the society to remember, negates, and force the separation between the society from the events that happened in the past. This research was done by Seroussi \& Teeger (2010) about the denial of the death commemoration Yitzhak Rabin, Israel soldier who died during the Israel war also revealed that the collective memory denial on the traumatic event in the past is the mechanism that neatly arranged, systematic, and planned. They called this mechanism is the covert silence of forgetting towards the past negativity. The planning and systematization of the collective memory denial can be traced from the relations between events before the tragedy happened until today. Zerubavel (2006) stated that this denial also can be abstracted from the reflection of the victims' family on those events.

The patterned forms of collective memory denial which was revealed in this research are as follows; (a) there efforts to drag the time of disclosure that done by the government institutions, such as excecutive, yudicative, and legislative institutions which oblige to resolve the TSS case, (b) there efforts to eliminate the facts about the tragedy that has been prove empirically with the disappearance of investigation file KPP TSS National Commission on Human Rights in General Attorney, (c) there also ignorance and silenced that done by the state towards the informants' complaints and victims' family on the poor performance of the institution that obliged to solve the case, (d) there exist the scenario to sacrifice the subordinates as field excecutor in covering up the involvement of important people in this case, (e) there effrots to distort the facts about the case that revealed through judicial process in legislative institution, (f) there political intervention that done by the House of Representative (DPR) as legislative institution to tackle the case in order not being legally proceed, $(\mathrm{g})$ there efforts in grounding the facts that the victim was being treated well, such as by given the compensation, facility until the title of the Reform Fighters. Where in reality, informant confess they never receive all of that as well as the title of the Reform Fighters just a babble since that this situation has no implication in the case continuation, (h) the stigmatization that attached on student victims who labelled as rioter, while the soldier who struggle were a hero and (i) there offensive blocking efforts towards the past by spreading the threats, terror, and prohibitions for the informant to access their collective memory about the past.

Generally, the patterned of collective memory denial which is formulated in this research has similarity with the denial pattern, however there are several points from the denial pattern in this research that is not mentioned by Cohen (2001) in his book, that is the point about the political intervention, the offensive blocking towards the past, and neglect the victim. Cohen (2001) did not close the possibility of the patterned collective memory denial which is different and unique in every negative event that face by some groups or nation. Particularly within the violation of human rights in democracy era which has a various pattern. The successors in silence create oppressive circuits to the memory. Meanwhile, the victims' family and the bystander (non-victim civil society) who make efforts to reveals the truth about the tragedy were unable to do anything because they are 
too powerless in the face of this cycle of denial. Even though, historian, journalist, an academician from various disciplines as well as a human rights activist who involves in a Non-Governmental Organization trying to be a whistleblower in this case.

Another research that done by Welch (2003) stated that this denial becomes legitimate if it is done publicly, collectively, and organized. Not as the denial that done blindly by the totalitarian regime who done the offensive efforts to rewrite the history and blocking the past in order it cannot be accessed. The collective memory denial that happened within the democratic society turn out served as public agenda. Which makes the society unconscious when being swept away within the mechanism of denial. This is proven in the context that being researched by the researcher. Since that, if reviewing again the interview results from the informants, not many people who were care and willing to talk about Trisakti and Semanggi case. They tend to be silent and reluctant to talk about it again. As a result, the current generation does not know about the tragedy.

The exposure of the fact about the negative event in the past potentially appearing the moral panic (Welch 2003) in this research. Tait \& Silver (1989) argued that the process of social division about the past painful memory even could bring emotional divide along with the moral anxiety which is very disturbing within the society. As the consequence, the society forms their social identity in a negative way. The reflection process of the negative past memory was able to create new polarization in the society. Which later on, it could damage the social cohesiveness. It means that the reflection process is understood as an awareness form which is addressed directly in a certain events or period that can be automatically and simultaneously process. It also can be seen as the unintentional and obsessive thoughts which related with a certain event. This process heavily related to the collective psychological depression and potentially extends the negative emotional reaction inside the society.

Berinstain et al. (2000) stated the opposite argument when the social division process was inhibited it will cause the negative effects in that community. It creates the silenced attitude and fear to the society particularly when they talk about their groups' past. The recurring violent event inflicts a culture of fear, which as the consequence cutting the community's ability to make healthy communication with each other. Besides it also cause the individual atomization symptom in modern society, which means that there happen social isolation and prejudice between groups (Wattimena 2008).

Different story when the social division was conducted continuously, it able to solve the emotional problem on a traumatic event. The evidence in the next research confirmed that the social division able to develop individual subjective well-being inside the community in the short or long term. Rime et al. (1997) continue if the process of the social division were capable to restore the individual self-concept, which is affected by the emotional moment that challenges the belief system of the individual and their established world. This social division, then able to push a group to discuss, express, and cope with their painful trauma in the past.

The pattern of collective memory denial efforts that done by the state, there exists an attempt to eliminate the conversation about a negative event that happened in the past (Wattimena 2008 and Cohen 2001). In this process, the society was blocked to know what really happened. In remembering the process and learn from the past mistakes did not happen. In effects, there is the social price that must be paid heavily, that is the spreading of impunity culture that covers us. If the denial were done and left for a long time then the rehabilitation efforts also need a long time in order to arrive in the reconciliation phase (Bar-Tal 2003). When let the negative event unfinished it means that it also let the prejudice to happen, distrust, hate, and revenge between individual. The most painful for the victim is the collective memory denials that opening up their room of suffering even more with the second victimization that they had experienced. After finding their beloved families were killed by the state, they have to face psychological fatigue as an impact they did not obtain their rights such as receiving the rehabilitation, restitution, and compensation. In addition, the prejudice that attached to their son as rioters is served as a hurtful insult which further aggravated their psychological wounds over the negative events. This prejudice creates hates between the society and this is the breed of new violence (Haryatmoko 2003, and Hardiman 2005). 
The commemoration efforts that are done by the informants routinely was seen as the social functions that are very important to conserve the collective memory of the victims' family. By doing commemoration, the individual memory transformed as belongs together as well as affirmed the continuation existence of individual memory in a certain community. In the context of social trauma, the commemoration has an important meaning as distribution tools individual meaning which resulting in the growth of solidarity feeling within the society. It proved by Berinstain et al. (2000) who done the research to Maya people in Guatemala who experience genocide trauma and this also happened in this research context. The social sharing collective memory that is painful that face by community served as the individual mechanism to access their people history (Middleton \& Brown 2005). Besides that, explicitly a group capable to remember well rather than individual, while the commemoration efforts are an empirical representation that group are able to remember like an individual. Moreover, the commemoration that done by the informants and their colleagues who face the same experience needs to be continuously held and fight for in order appear regeneration. Therefore, the sustainability in the efforts to defend the counter memory about Trisakti and Semanggi tragedy can be more assured (Weldon \& Bellinger 1997, and Berinstain et al. 2000).

This commemoration will be meaningful if it was done by the state after the state complete the judicial case and sincerely punish the perpetrators and uncover the facts about the events, then commemorate the negative tragedy publicly, not just done by the victims' community with the affirmation that the same mistake should not happen again in the future.

\section{Conclusion}

The conclusions that can be drawn from the whole research process are as follows; the first is there are efforts of collective memory denial the victims' family of Trisakti, Semanggi I, and Semanggi II tragedy systematically, planned, and patterned that done by the state represent through the institutions of the state. Second, the collective memory denial has nine patterns that already explained in the previous section. Third, the victims' family of Trisakti, Semanggi I, and Semanggi II tragedy has commemoration mechanism such as memorialize the decease that they do each year, tribute the name of the victims as the road name, as well as the monument construction. This commemoration served as the representation from the social sharing process or distribution collective memory from the victims' family as the counter-memory from the official memory.

\section{Acknowledgement}

We are very grateful of the help provided by Komisi untuk Orang Hilang dan Korban Tindak Kekerasan (KONTRAS). They provided access to our participants and kindly allowed us to interview one of its officer as a significant other. Bahasa version of this manuscript is available upon request by contacting the corresponding author.

\section{References}

Bar-Tal D (2003) Collective Memory of Physical Violence: Its Contribution to the Culture of Violence. In: E Cairns \& MD Roe (eds). The role of memory in ethnic conflict. 77-93.

Beck U (1992) Risk Society, Towards a New Modernity. London: SAGE Publication.

Berinstain CM, Paez D, \& Gonzalez JL (2000) Rituals, social sharing, silence, emotions, and collective memory claims in the case of the Guatemalan genocide. Psicothema, 12:117-130.

Bonasahat AY (2007) Perjuangan melawan lupa. [Accessed 1 October 2009]. http://www.atmajaya. ac.id/content.asp? $\mathrm{f}=0 \& \mathrm{id}=2245$.

Cohen S (2001) States of Denial: Knowing about atrocities and suffering. Cambridge: Blackwell Publishing.

Halbwasch M (1992) On Collective Memory. Chicago: University of Chicago Press. 
Hardiman FB (2005) Memahami Negativitas: Diskursus tentang Massa, Teror, dan Trauma. Jakarta: Kompas.

Haryatmoko (2003) Kejahatan menjadi hal biasa. Kompas, 2003. [Accessed 1 October 2009]. http:// www.kompas.co.id/kompas-cetak/0309/03/opini/527239.htm.

Haryatmoko (2008) Ingatan sosial dan proses hukum. Kompas, 2008. [Accessed 1 October 2009]. http://www.kompas.com/kompascetak/read.php?cnt=.kompascetak.xml.2008.02.12.

Kertas Posisi KontraS, Kasus Trisakti, Semanggi I dan II. (2005) Komisi Untuk Orang Hilang dan Korban Tindak Kekerasan. [Accessed 1 October 2009]. http://www.kontras.org/data/ KERTAS_POSISI_TSS_2006.pdf.

Kuzmanic M (2008) Collective memory and social identity: A social psychological exploration of the memories of the disintegration of former Yugoslavia. Horizon of Psychology, 17 (2):5-26.

Middleton D \& Brown SD (2005) The Social Psychology of Experience. London: SAGE Publication.

Patton MQ (2001) Qualitative Research and Evaluation Method. London: SAGE Publication.

Poerwandari EK (2007) Pendekatan Kualitatif untuk Penelitian Perilaku Manusia. Jakarta: LPSP3 Universitas Indonesia.

Seroussi VV \& Teeger C (2010) Unpacking the unspoken: Silence in collective memory forgetting. Social Forces, 88 (3):1103-1122.

Tait C \& Silver AD (1989) Coming to Terms with Major Negative Life Events. In JS Uleman \& J Bargh (eds). Unitended Thought. New York: Guilford. 351-382.

Wartiharjono S (2017) Potensi konflik dan pembentukan modal sosial: belajar dari sebuah desa transmigran di Kalimantan Timur. Masyarakat, Kebudayaan dan Politik, 30 (1):84-93.

Wattimena RAA (2008) Ingatan sosial, trauma, dan maaf. Jurnal Respons, 13:20-41.

Welch M (2003) Trampling human rights in the war on terror: Implication to the sociology of denial. Critical Criminology, 12:1-20.

Weldon MS \& Bellinger KD (1997) Collective memory: Collaborative and individual processes in remembering. Journal of Experimental Psychology: Learning, Memory, and Cognition, 23 (5):1160-1175.

Zerubavel E (2006) The Elephant in the Room: Silence and Denial in Everyday Life. Oxford: Oxford University Press. 